\title{
The Implementation of Indonesian Labor Law to Legal Protection on the Rights of Outsourced Labor in Private Companies in Medan
}

\author{
Daniel $^{1}$, Suparno $^{2}$ \\ \{apin_204@yahoo.com¹, suparno@borobudur.ac.id²\} \\ Universitas Borobudur, Jakarta, Indonesia ${ }^{1,2}$
}

\begin{abstract}
The presence of outsourced laborers in companies in Indonesia raises many problems, especially viewed from a legal point of view. Several protests demanding the fulfillment of the rights of outsourced labors can be used as initial evidence that Law Number 3 of 2003 concerning Labor has not been able to provide legal protection to the rights that outsourced laborers must obtain. This paper aims at finding out the implementation of the Labor Law on the legal protection to the rights of outsourced laborers employed in private companies in Medan. This study used a normative juridical method. The data were both primary and secondary data. The preliminary data were collected from the questionnaires and interviews, while the secondary data were obtained from legal documents, including Labor Law, outsourcing contracts, and journal articles. The participants were outsourced laborers and employers hiring outsourced laborers in their companies in Medan. The results of data analysis show that the rights of outsourced laborers employed in private companies in Medan are not well provided. There needs to be a law regulating strict legal protection on outsourced workers employed in companies in Medan.
\end{abstract}

Keywords: Labor Law; legal protection; outsourced labors; private companies

\section{Introduction}

Workforce issues are regulated in Article 1 paragraph (2) of Law Number 13 of 2003 concerning Manpower. Article 1 paragraph (2) of the Manpower Law Number 13 of 2003 states that all people may work, both men and women, can carry out work activities and produce goods or services that are useful for themselves and the wider community. In addition, the meaning of labor here is comprehensive, covering all state officials such as the President, Chair, and Members of the DPR, DPA, MPR, Ministers, all state employees, both civil and military and police, all entrepreneurs, workers, self-employed, and so on.

However, in this case, the author will discuss the outsourcing of labor, outsourcing workers, or what is often called outsourcing in the law is not explained directly.[1] Still, the arrangement is seen in Law Number 13 of 2003 Article 64 states: the implementation of work to other companies through a contractual agreement for work or the provision of labor services 
made in writing, and in the Civil Code 1601 letter bit is stated that outsourcing is equated with a chartering agreement.[2]

The state of Indonesia has a lot of outsourced workers and also many outsourced/outsourced workers who hold demonstrations because they feel that the company is not paying attention to the welfare of its workers and hope that the company makes a company policy that pays more attention to the rights of the outsourced/outsourced workers.[3] And also protect the rights of outsourced workers. The working period of the outsourced workers starts from the beginning when there is a contract agreement with the work contract between the company and the workers. [4] Even though the service period has been for many years, the service period is calculated from the time the contract was agreed to be renewed, and this is detrimental to the workforce when there is the termination of the unilateral relationship work by the company because workers cannot demand normative rights like ordinary workers.[5]

Severance pay is regulated in Article 156 paragraph (2) of Law Number 13 of 2003 concerning Employment, housing, and medical reimbursement (Article 156 paragraph (4) and compensation for the relevant annual leave upon termination of work, as well as salary calculated from the time of dismissal). Is not the right of outsourced workers.

The outsourcing/outsourcing contract work system that prioritizes a very young workforce will narrow the job opportunities for workers aged $>30$ years. Suppose employment opportunities in the formal sector for the older workforce are narrowed. In that case, there will be an explosion in the informal sector that has dominated the Indonesian workforce structure. In daily operations in carrying out work activities within a company, there is an error that results in work accidents or physical losses experienced by workers, which is very disturbing for workers.[6]

Good relations between outsourced workers and companies will lead to a higher quality working relationship where workers will feel more respected. Their rights are protected to perform their work obligations to the fullest because all their requests are well fulfilled. For this reason, it is necessary for the government's role as a party that is directly involved in the employment relationship can be neutral and can guarantee the implementation of the rights and obligations of the parties in the employment relationship, as in Law Number 13 of 2003 concerning Manpower which states "every worker/laborer has the right to obtain equal treatment without discrimination from employers."

Various problems regarding the legal protection of workers, in reality, are still less than expected. This can be seen from the implementation that is outside of what has been stipulated in the labor legislation, where there are still entrepreneurs who make their regulations for the benefit of the company who ignore the rights of the workers themselves, which workers cannot claim their rights in this era of globalization. Nowadays where many companies use a contract system with certain time workers.

\section{Methods}

The scope of this research is limited to the problems that the author examines, namely to find out how the company's role in fulfilling the rights of outsourcing workers and how the legal protection of outsourcing workers is following Law Number 13 of 2003 concerning Manpower. The research that will be conducted is normative legal research and empirical legal research. The first step is normative legal research based on primary and secondary legal materials, namely an inventory of regulations relating to the Protection of Outsourcing 
Workers. In addition, written materials related to the Company's Role in Fulfilling the Rights of Outsourcing Workers in Medan, North Sumatera, are also used.

The research aims to find a clear legal basis in placing this issue in the perspective of labor law. Then it is associated with empirical legal research, where this research seeks to see how this problem is implemented in practice. The material or data sought is in the form of secondary data consisting of:

a. The primary source of law is statutory regulations, namely No. 13 of 2013 concerning Manpower and other relevant laws and regulations.

b. Secondary legal sources in the form of other reference materials that contain information on primary materials in the form of writings/books related to labor law.

The method used to analyze qualitative analysis data is that the data obtained are compiled systematically and then analyzed qualitatively to achieve clarity of the problems to be discussed. The results are stated in the form of a paper.

\section{Discussion}

\subsection{Legal Protection for Workers}

The employment relationship through outsourcing is an effort to get around the law, both before enacting the Republic of Indonesia No. 13 of 2003 and after it. Although the new law implicitly does not justify such employment relationships for permanent or continuous work and is only justified for specific jobs and for a period not more extended than that stipulated by law, it can still be managed in various ways. The method of determining the provisions of the job description and the time being cut off and by changing the name of the outsourcing company.

These outsourced employees don't have many other choices where national open unemployment exceeds 11.6 million people, closed unemployment 30 million people from a labor supply of more than 106.9 million people. Meanwhile, many companies closed because they could not compete with imported products, while export products also declined domestically due to high production costs. They were also forced to accept a worse fate than the 11,000 employees who demonstrated in Surabaya demanding an increase in the regional minimum wage. They can sue because the labor supply company has no assets and can close and change another company's name at any time.

These outsourced workers need to be given legal protection for the reason of saving a workforce that has a lot of potentials, one way or another, the right to carry out general economic progress.[7] Most of these outsourcing workers are professionals in their fields, young in age, and have a good work ethic. Their weakness is mainly because they do not have the opportunity and do not have a special relationship with policymakers.[8] They also came later compared to the permanent forces because indeed they also came later in the world. This potential workforce also needs to be protected because if the nation's economic development movement starts again, this workforce will still be available and ready to welcome the postcrisis economic rebuilding movement in Indonesia. The reality in developed countries shows that no matter how modern the production process is, reliable and high-spirited operators are still needed so that they are still employed today.[9]

Although the most recent labor law has been regulated, some loopholes can still be exploited. In the problem of controlling this gap, in general, the labor supply company shows 
its expertise. The position of workers is always in a weak place, both in front of labor supply companies and in front of companies that use labor.

Because workers come from various places and most of them work for a limited time, i.e., three years on average, of course, they are not easy to organize. Getting into a permanent worker organization is also not easy because they are usually considered competitors, especially willing to accept salaries and wages. The lower rights of permanent workers so that the bargaining position of permanent workers is also shaky in front of companies that use labor. So, these outsourced workers become squeezed workers and are forced to accept their fate, including when they suddenly have to stop because the employer wants to be efficient.[10]

Law of the Republic of Indonesia No. 13 of 2003 concerning Manpower does not explicitly mention outsourcing. Still, Article 64 indirectly says outsourcing, namely, "Companies may hand over part of the implementation of work to other companies through work chartering agreements or the provision of workers/labor services made in writing.

The definition of outsourcing is equated with a job chartering agreement. Meanwhile, according to Article $1601 \mathrm{~b}$ of the Civil Code, the contract of contracting work is an agreement in which the contractor binds himself to make a specific job for another party who does the contracting by receiving a certain fee and the other party who does the contracting binds himself to buy the job to the contractor for a specific price.

Based on the above understanding, an operational definition of outsourcing can be drawn, which is a form of work agreement between company A as a service user and company $\mathrm{B}$ as a service provider, where company A asks company B to provide the necessary Manpower to work at Company A by paying a fixed amount of money and wages or salaries paid by Company B.

Law of the Republic of Indonesia No. 13 of 2003 concerning Manpower regulates the conditions for companies that can provide Manpower so that the interests of the parties involved in the Outsourcing Agreement are not harmed, especially outsourcing workers who are usually in a weak position. These conditions are stated in Article 66 of the Law of the Republic of Indonesia No. 13 of 2003, among others:

a. workers/ laborers with companies providing services for workers/ laborers;

b. A work agreement that applies in an employment relationship is a work agreement for a particular time that meets the requirements

c. as contained in Article 59 of the Law of the Republic of Indonesia No. 13 of 2003 and an indefinite work agreement made in writing and signed by both parties.

d. Protection of wages and welfare, working conditions, as well as disputes that arise are the responsibility of the worker/labor service provider company;

e. Agreements between companies that use worker/labor services and providers of worker/labor services are made in writing and must contain the articles referred to in this law;

f. Workers' service providers must be legal entities and have permits from the employment agency.

Suppose the provisions as mentioned earlier are not met by law. In that case, the employment relationship between the worker and the company providing the worker's services will change to a working relationship between the worker/laborer and the company providing the job.

\subsection{Barriers to the Implementation of Outsourcing Labor Law Protection}


The industrial relations policy aims to create harmonious, dynamic, fair, and dignified industrial relations in an ever-growing company. To achieve this goal, industrial relations policies must answer the challenges that are developing following the dynamics of industrial relations. The condition of industrial relations in a country is very vulnerable to change because it is influenced by several factors, both external and internal, namely:

1. Labor conditions that are structural in nature, namely high unemployment, low numbers of the quality of the workforce, and the level of welfare of the workforce.

2. Changes in the strategic environment covering all aspects of life in the nation and state, starting with the economic crisis that brought down business performance, causing more layoffs which then demanded the need for reform in the field of Industrial Relations which was marked by demands for increased protection of workers and improvement of requirements. - working conditions and the application of freedom of association resulted in a significant change in the number of unions, namely from single unions to multi unions.

3. Globalization, among others, is marked by solid demand for the implementation of universal standards. Any treatment that ignores the fundamental rights of workers, as stated in the ILO Conventions, will always be a concern of the world community. While on the other hand, companies are required to improve efficiency and productivity in the face of global competition. Therefore, it is understandable that new forms of business management will emerge which imply flexibility of working relations, such as contracting systems, outsourcing, or tailoring orders.

All phenomena of changes that occur in the implementation of industrial relations must be observed together. The number of demonstrations is an indication that the current practice of industrial relations needs to be reviewed regarding the effectiveness of its implementation. Several protests are often colored with lawless actions, and it is not impossible to carry political interests. Industrial relations problems are essentially challenges that are faced and arise as a result of changes in values, including:

1. The implementation of industrial relations is faced with the obligation to contribute to creating a conducive business climate for investment

2. The phenomena of reform, freedom of association, democratization, implementation of human rights, the rule of law, and Autonomy impact industrial relations in companies.

3. With the phenomenon of globalization, the application of international standards, increasing competitiveness, entrepreneurs take efficient and productive management to tend to have a flexible form of work relations.

4. Needs (human needs) are constantly increasing.

5. The role and function of industrial relations facilities that have not been optimally defined as 'PP. PKB, Bipartite LKS. Tripartite LKS. The role of SP/SB. Employers' Association, Manpower Regulations, and Industrial Relations Dispute Settlement Institutions.

The implementation of the employment relationship in outsourcing is regulated in Article 65 paragraph (6) and (7) and Article 66 paragraph (2) and (4) of the Law of the Republic of Indonesia No. 13 of 2003. The regulation also addresses all the broad and complex problems of outsourcing. However, it can provide legal protection for workers/laborers, especially those concerning working conditions, working conditions, social security, and other worker protections, and can be used as a reference in solving problems if there are problems.

In certain circumstances, it isn't easy to define/determine the work categorized as supporting. This can happen because of differences in perception and sometimes also motivated by the interests that are represented to benefit from these conditions. Besides that, the forms of business management are very varied, and several multi-national companies in 
the era of globalization have brought new forms of business partnerships, adding to the confusion.

\section{Conclusion}

Legal protection for workers contains two elements, namely preventive and repressive legal protection. In preventive legal guardian, the goal is to avoid disputes. One of its forms is the participation of the community in the laws and regulations that have been passed. Unfortunately, this has not been implemented in Indonesia, and it is often the case that a law that has been given has never had an academic text.

Outsourced workers' rights to Jamsostek are not clearly stated in their work agreements. Outsourced workers at PT. Jamsostek includes the right to receive guarantees from 4 Jamsostek programs, namely: 1. Work accident insurance program, 2. death insurance program, 3. old-age savings insurance program, and four health care insurance programs. But the question is about the right to the old-age savings program because the outsourcing work agreement is a maximum of 2 years.

The will to get a decent wage is far from the expectations of the outsourced workers. For permanent workers, it is not necessarily a decent wage. But at least there is creativity in determining the wage scale, for example, through wage tiers. Likewise, outsourced workers can't obtain retirement savings, even though they always extend the agreement from time to time. Therefore, there needs to be firmness in the laws and regulations that the outsourced worker must be appointed as a permanent employee at the company after the first or second contract expires.

In case of a disconnection employment relationship, employers may be required by P4-D or p.N. (In-Law No. 2 of 204, it is called the Industrial Relations Court) to pay severance pay (UP) and service award money (UPMK) and compensation for rights (PH). Obstacles that occur in implementing legal protection for outsourced workers based on Law Number 13 of 2003 concerning Manpower. The condition of industrial relations in a country is very vulnerable to change because it is influenced by external and internal factors to the workforce.

\section{References}

[1] M. Ferdosi, "The development of Swedish employment protection legislation," Labor Hist., vol. 61, no. 5-6, pp. 568-585, 2020, doi: 10.1080/0023656X.2020.1830957.

[2] U. Kholifah, "Pelaksanaan Perlindungan Hukum Bagi Tenaga Kerja Outsourcing Berdasarkan Undang-Undang Republik Indonesia No. 13 Tahun 2003," J. Spektrum Huk., vol. 14, no. 1, pp. 44-70, 2017.

[3] N. Witney, "Building Europeans' Capacity to Defend Themselves," no. May, 2019.

[4] D. Kurniawan, A. Sutan, I. Mufandi, E. Supriyanto, and M. Rachmawati, "Social Media Used to Spread Vaccination Program: Case of Indonesia Vaccination Covid-19 Policy," 2021, doi: 10.4108/eai.6-3-2021.2306469.

[5] P. Guha, A. Mandal, and A. Mitra, "Do labor rights help to protect human rights? An empirical exploration," Appl. Econ. Lett., vol. 28, no. 2, pp. 161-164, 2021, doi: 10.1080/13504851.2020.1739610.

[6] D. Raess, A. Dür, and D. Sari, "Protecting labor rights in preferential trade agreements: The role of trade unions, left governments, and skilled labor," Rev. Int. Organ., vol. 13, 
no. 2, pp. 143-162, 2018, doi: 10.1007/s11558-018-9301-z.

[7] A. Palatnik and J. J. Mcintosh, "Protecting Labor and Delivery Personnel from COVID-19 during the Second Stage of Labor," Am. J. Perinatol., vol. 37, no. 8, pp. 854-856, 2020, doi: 10.1055/s-0040-1709689.

[8] B. V. Sevastyanov, E. B. Lisina, N. V. Selyunina, R. O. Shadrin, and A. V. Shalamova, "Interrelation of regulatory legal acts regulating professional functions of the labor protection specialist," IOP Conf. Ser. Earth Environ. Sci., vol. 408, no. 1, 2020, doi: 10.1088/1755-1315/408/1/012027.

[9] E. S. Egorova, N. V. Vadullina, A. O. Salimov, Y. N. Savicheva, and A. A. Gilyazov, "Modern concepts for organization of labor protection at oil and gas processing enterprises," IOP Conf. Ser. Earth Environ. Sci., vol. 548, no. 6, 2020, doi: 10.1088/1755-1315/548/6/062027.

[10] G. Ciminelli, R. Duval, and D. Furceri, "Employment Protection Deregulation and Labor Shares in Advanced Economies," IMF Work. Pap., vol. 18, no. 186, p. 1, 2018, doi: 10.5089/9781484370087.001. 